\title{
Effects of Interpersonal Communication and Compensation on Employee Performance of PT Panen Jaya Sepasang Palembang
}

\author{
Richo Mahendra' ${ }^{1)}$, Luis Marnisah ${ }^{2)}$, Muhammad Wadud ${ }^{3)}$ \\ 1), 2), 3) Universitas Indo Global Mandiri, Indonesia \\ Email: richomahendra1818@gmail.com ${ }^{1)}$,luismarnisah@gmail.com ${ }^{2}$,wadud@uigm.ac.id)
}

\begin{abstract}
This study aims to investigate the effects of interpersonal communication and compensation on the performance of employees of PT Panen Jaya Sepasang Palembang. A sample of 90 respondents were obtained using a nonprobability sampling technique. Data were collected through questionnaires and observations, and analyzed employing the multiple linear regression method. The results evince that partially each interpersonal communication and compensation has a significant effect on employee performance. Likewise, simultaneously, interpersonal communication and compensation have a significant effect on employee performance. This research is beneficial for PT Panen Jaya Sepasang Palembang. To improve employee performance, the company must pay attention to interpersonal communication and compensation factors.
\end{abstract}

Keywords: interpersonal communication, compensation, human resource management

\section{Introduction}

Humans basically have to communicate and socialize, interact with other humans, meaning that the existence of an organization is expected to be a forum that brings together its members to communicate, interact, and socialize with leaders and colleagues in the organization. Communication is basically part of the activities that humans do in their daily life. Humans communicate to give and receive information according to their needs. When communicating, someone will feel the results of the communication such as feedback and getting the desired information (Agustin \& Widayatmoko, 2019). According to kasmir (2016) compensation is the remuneration provided by the company to its employees, both financial and non-financial. This means that the company will provide remuneration to all employees involved in it.

Based on information from Mrs. Shinta as the deputy director, she stated that there are still frequent miscommunications or misunderstandings in the delivery of information between the leadership and employees which have an impact on expected performance. In addition, there are still frequent delays in completing the company's targets, so the compensation given is not so great. This study aims to determine the extent to which interpersonal communication and compensation affect the performance of employees of PT. Panen Jaya Sepasang. The following is the employee performance data of PT. Panen Jaya Sepasang. 
Tabel 1. Performance of employees PT. Panen Jaya Sepasang

\begin{tabular}{|c|l|c|c|c|c|}
\hline \multirow{2}{*}{ No } & \multirow{2}{*}{ Elements } & \multicolumn{2}{|c|}{ year 2018 } & \multicolumn{2}{c|}{ year 2019 } \\
\cline { 2 - 6 } & Value & Description & Value & Description \\
\hline 1 & Faithfulness & 85 & good & 80 & good \\
\hline 2 & $\begin{array}{l}\text { Work } \\
\text { performance }\end{array}$ & 85 & good & 80 & good \\
\hline 3 & Responsibility & 80 & good & 75 & Pretty good \\
\hline 4 & Obedience & 79 & Pretty good & 75 & Pretty good \\
\hline 5 & honesty & 80 & good & 80 & good \\
\hline 6 & Cooperation & 85 & good & 75 & Pretty good \\
\hline 7 & communication & 80 & good & 75 & Pretty good \\
\hline 8 & leadership & 85 & good & 80 & good \\
\hline & Amount & 659 & & 620 & \\
\hline & Average & $82,3 \%$ & good & $77,5 \%$ & Pretty good \\
\hline
\end{tabular}

Source: PT. Panen Jaya Sepasang, 2019

From the data above, it can be seen that the average value of employee work has decreased from year to year. If you look at the total average value of the work of employees of PT. Panen Jaya Sepasang. In 2018-2019, it decreased by 4.8\%. Meanwhile, when viewed based on the work result assessment scale, the lowest average employee work result occurred in 2019 which was in the category of Fairly Good rating scale (70-79). Whereas the previous years were in the Good category (80-89). This happens because employee performance is still not optimal, so it can be seen in the total average value of employee work and one of the factors that decrease employee performance is that there is still miscommunication between co-workers, such as differences in perceptions between sending information and receiving information. The work does not run smoothly and results in delays in work and can cancel the company that will provide compensation if the company's target is not on time because of this factor.

The research according to Pertiwi et al., (2019) shows a positive influence between interpersonal communication variables and compensation on employee job satisfaction. According to Bayu Purnawati et al., (2019) compensation has a positive and significant effect on employee performance. 


\subsection{Research Problem}

Based on the research background that has been stated previously, the problems in this research are:

1. How does Interpersonal Communication influence Employee Performance at PT. Panen Jaya Sepasang Palembang?

2. How is the effect of compensation on employee performance at PT. Panen Jaya Sepasang Palembang?

3. How is the influence of Interpersonal Communication and Compensation on Employee Performance of PT. Panen Jaya Sepasang Palembang?

\subsection{Research Objectives}

The purpose of this research is to find out, analyze and prove

1. The Influence of Interpersonal Communication on Employee Performance at PT. Panen Jaya Sepasang Palembang

2. The Effect of Compensation on Employee Performance at PT. Panen Jaya Sepasang Palembang

3. The Influence of Interpersonal Communication and Compensation on Employee Performance at PT. Panen Jaya Sepasang Palembang

\section{Literature Review}

\subsection{Interpersonal Communication}

The term communication or communication comes from the latin, namely communication means notification (wiryanto, 2020). The essence of communication is an effort to convey messages to other parties, so that there will be a transfer and exchange of information from the communicator to the communicant. In the two-way communication process, the communicator and the communicant switch roles between each other. Indicators of Interpersonal Communication According to nurdin (2020)

1. Affinity: This dimension is related to the extent to which people are related or like each other. One can see the dimensions through the categories of people's preferences for others.

2. Respect (Respect): This dimension is related to the extent to which we admire other people and they feel admired.

3. Immediacy (closeness): This dimension is related to the image of a person's closeness when communicating with other people.

4. Control (Control): This dimension is related to how communication control is applied by the party who is communicating.

\subsection{Compensation}

According to kasmir (2016)) compensation is the remuneration provided by the company to its employees, both financial and non-financial. This means that the company will provide remuneration to all employees involved in it. The remuneration provided is the company's obligation for the hard work given to the company during work. On the other hand, for employees, compensation is the employee's right to the burdens and responsibilities given to 
the company. So compensation for the company is an obligation that must be given, while for employees it is a right that must be received. Compensation Indicators According to Nawa \& Kempa (2017)

1. Salary and wages are fair according to the work.

2. Incentives that match the sacrifices.

3. Allowances in line with expectations.

4. Adequate facilities.

\subsection{Framework}

This study examines how the influence of the development of Interpersonal Communication and Compensation on Employee Performance. There are three variables tested in this study, namely: Interpersonal Communication and Compensation as the independent variable and employee performance as the dependent variable. Interpersonal Communication and compensation variables allegedly affect the performance of employees at PT Panen Jaya Sepasang. Therefore, researchers will conduct further research to determine the effect of Interpersonal Communication and Compensation on Employee Performance PT Panen Jaya Sepasang

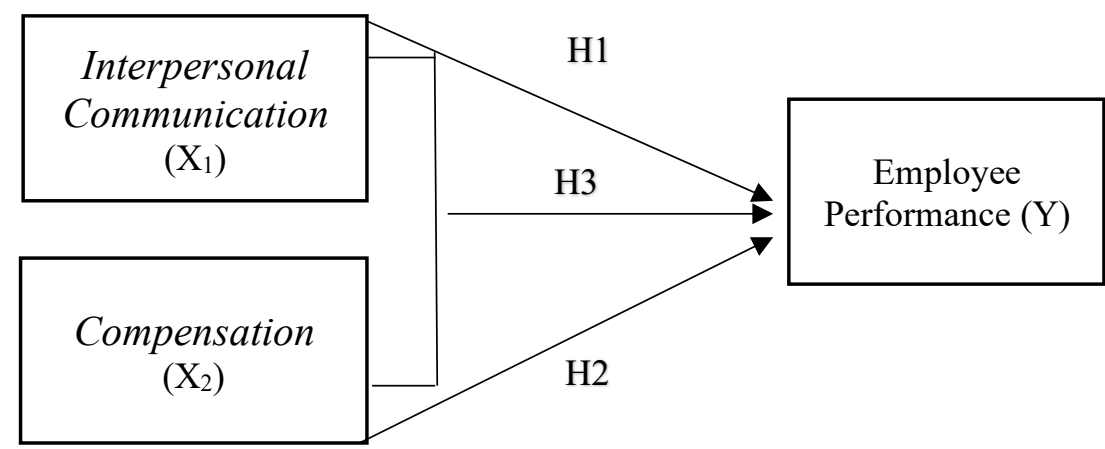

Figure 1. Framework

\section{Research Method}

\subsection{Types and Sources of Data}

In conducting the research, the writer tries to collect the required data and information as accurately as possible. For this reason, the author uses several methods or methods in collecting data needed in research. Sources of data used in this study:

1. Quantitative Data

According to Hermanto (2020) quantitative data is data in the form of numbers, or quantitative data that is scored (scoring). So quantitative data is data that has a tendency to be analyzed by means or statistical techniques. The data can be in the form of numbers or scores and are usually obtained using a data collection tool whose answers are in the form of a range of scores or weighted questions.

2. Qualitative Data

According to Sugiyono (2020) qualitative data is data in the form of sentences, words or pictures. 
To support this research and obtain the required data, the data sources used are primary data and secondary data. Primary sources are data sources that directly provide data to data collectors. This primary data in the form of interviews and questionnaires made by researchers. Secondary sources are sources that do not directly provide data to data collectors, for example through other people or documents Sugiyono (2020).

\subsection{Population and Sample}

According to Sugiyono (2020)population is a generalization area consisting of objects and subjects that have certain qualities and characteristics determined by research to be studied and then drawn conclusions. The population in this study were all employees who worked at PT Panen Jaya Sepasang, totaling 90 people. According to Sugiyono (2020) defines the sample as part of the number and characteristics of the population. The sample is part of the population that has certain characteristics or conditions to be studied and is considered to represent the entire population. Sampling in this study used non-probability sampling with saturated sampling technique where the entire sample was taken from a population of 90 respondents.

\section{Findings and Discussions}

Multiple linear regression analysis was used to analyze the effect of the independent variable on the dependent variable.

Table 2. Multiple Linear Regression Analysis Results

\begin{tabular}{|c|c|c|c|c|c|c|}
\hline \multicolumn{7}{|c|}{ Coefficients $^{\mathrm{a}}$} \\
\hline \multirow{2}{*}{\multicolumn{2}{|c|}{ Model }} & \multicolumn{2}{|c|}{$\begin{array}{l}\text { Unstandardized } \\
\text { Coefficients }\end{array}$} & \multirow{2}{*}{$\begin{array}{c}\begin{array}{l}\text { Standardized } \\
\text { Coefficients }\end{array} \\
\text { Beta }\end{array}$} & \multirow[b]{2}{*}{$\mathrm{t}$} & \multirow[b]{2}{*}{ Sig. } \\
\hline & & B & Std. Error & & & \\
\hline \multirow[t]{3}{*}{1} & (Constant) & ,725 & ,277 & & 2,619 & , 010 \\
\hline & KI &, 183 &, 043 & ,268 & 4,238 &, 000 \\
\hline & K &, 630 & ,051 & ,788 & 12,448 & ,000 \\
\hline
\end{tabular}

a. Dependent Variable: KK

Source: Data processed with SPSS Version 24.0

Based on Table 2, the Multiple linear regression equation $\mathrm{d}$ as follows:

$\mathrm{Y}=0,725+0,183 \mathrm{X}_{1}+0.630 \mathrm{X}_{2}$

Description :

1. The constant of 0.725 states that if the independent variables of Interpersonal Communication and Compensation are considered constant, then the employee's performance is 0.725 . 
2. The positive interpersonal communication variable regression coefficient is 0.183 , which means that every increase in the interpersonal communication variable, it will increase employee performance interpersonal communication by 0.183 .

3. The regression coefficient for the positive compensation variable is 0.630 , which means that every increase in the compensation variable, the employee performance compensation will increase by 0.630 .

\subsection{Hypothesis Test}

\section{Partial Test Results ( $t$ Test)}

The t-value test is used to determine the level of influence of each independent variable on the dependent variable. An independent variable can be said how much influence on the dependent variable if the significance value generated in the test on each independent variable is smaller than the alpha value $(<0.05)$. The results of partial hypothesis testing for this study are as follows:

Table 3. Partial t-Test Results

\begin{tabular}{|c|c|c|c|c|c|c|}
\hline \multicolumn{7}{|c|}{ Coefficients ${ }^{\mathrm{a}}$} \\
\hline & & \multicolumn{2}{|c|}{$\begin{array}{l}\text { Unstandardized } \\
\text { Coefficients }\end{array}$} & \multirow{2}{*}{$\begin{array}{c}\text { Standardized } \\
\text { Coefficients } \\
\text { Beta }\end{array}$} & \multirow[b]{2}{*}{$\mathrm{t}$} & \multirow[b]{2}{*}{ Sig. } \\
\hline \multicolumn{2}{|c|}{ Model } & B & Std. Error & & & \\
\hline \multirow[t]{3}{*}{1} & (Constant) &, 725 & ,277 & & 2,619 & 010 \\
\hline & $\mathrm{KI}$ &, 183 & ,043 & ,268 & 4,238 & 000 \\
\hline & $\mathrm{K}$ &, 630 &, 051 &, 788 & 12,448 &, 000 \\
\hline
\end{tabular}

Source: Data processed with SPSS Version 24.0

The first hypothesis in this study is that interpersonal communication has an effect on employee performance. The hypothesis can be accepted if the resulting significance value is less than 0.05 and has a positive beta coefficient. The results for testing hypothesis 1 can be seen in table 4.12. Based on Table 4.12. It is known that the resulting significance value is 0.000 , which is smaller than 0.05 , meaning that the hypothesis is accepted. This shows that interpersonal communication has an effect on employee performance.

The first hypothesis in this study is that compensation has an effect on employee performance. The hypothesis can be accepted if the resulting significance value is less than 0.05 and has a positive beta coefficient. The results for testing hypothesis 2 can be seen in table 4.12. Based on Table 4.12, it is known that the resulting significance value is 0.000 , which is smaller than the number 0.05 , meaning that the hypothesis is accepted. This shows that compensation has an effect on employee performance. 


\section{Simultaneous Test Results (F-test)}

This test is conducted to determine whether the independent variables as a whole or simultaneously affect the dependent variable. Interpersonal communication and compensation variables together can be said to have an effect on employee performance if the resulting significance value is smaller than the alpha value $(<0.005)$. The results of testing the $F$ value can be seen in the table below

Table 4. F Value Test Results

\begin{tabular}{|l|l|r|r|r|r|r|}
\hline \multicolumn{7}{|c|}{ ANOVA $^{2}$} \\
\hline \multirow{2}{*}{ Model } & $\begin{array}{c}\text { Sum of } \\
\text { Squares }\end{array}$ & Df & $\begin{array}{c}\text { Mean } \\
\text { Square }\end{array}$ & F & Sig. \\
\hline \multirow{2}{*}{1} & Regression & 10.718 & 2 & 5.359 & 82.321 & $.000^{\mathrm{b}}$ \\
\cline { 2 - 7 } & Residual & 5.663 & 87 & .065 & & \\
\cline { 2 - 7 } & Total & 16.381 & 89 & & & \\
\hline \multicolumn{2}{|l|}{ a. Dependent Variable: Employee performance } & & \\
\hline \multicolumn{2}{|l}{ b. Predictors: (Constant), Interpersonal Communication, Compensation } \\
\hline
\end{tabular}

Source: The results of data processing using SPSS Version. 24.0.

In the table 4 , it can be seen that the significant value generated in this test is 0.000 , which value is smaller than 0.05 . This shows that the variables of interpersonal communication and compensation together have a significant effect on employee performance variables.

\subsection{Coefficient of Determination Test Results (Adjusted R2)}

The coefficient of determination test is useful to find out how much the independent variable is able to explain the dependent variable. The results of testing the coefficient of determination in this study can be seen in Table 4.13 below:

Table 5. Coefficient of Determination Test Results

\begin{tabular}{|l|l|l|r|r|c|}
\hline \multicolumn{7}{|c|}{ Model Summary $^{\mathbf{b}}$} \\
\hline Model & $\mathrm{R}$ & R Square & $\begin{array}{c}\text { Adjusted R } \\
\text { Square }\end{array}$ & $\begin{array}{c}\text { Std. Error of the } \\
\text { Estimate }\end{array}$ & $\begin{array}{c}\text { Durbin- } \\
\text { Watson }\end{array}$ \\
\hline 1 & $\begin{array}{l}.809 \\
\mathrm{a}\end{array}$ & $\begin{array}{l}.65 \\
4\end{array}$ & .646 & .2551 & 1.711 \\
\hline
\end{tabular}


Table 5 shows the $\mathrm{R}$ square value of 0.654 , so it can be seen that the independent variable in this study which includes interpersonal communication and compensation explains the employee performance variable of 0.654 or $65.4 \%$. The remaining value of $34.6 \%$ is another variable outside of this study which is able to explain the employee performance variable.

\section{References}

Agustin, R., \& Widayatmoko, W. (2019). Pengaruh Komunikasi Interpersonal dan Iklim Komunikasi Organisasi Terhadap Kepuasan Komunikasi Karyawan Sekretariat Jenderal Kementerian Komunikasi dan Informatika. Koneksi Vol. 3, No. 1, Juli 2019, Hal 163-169 EISSN 2598-0785, 3(1), 163-169. https://doi.org/10.24912/kn.v3i1.6198

Bayu Purnawati, E., Krisna Heryanda, K., \& Indah Rahmawati, P. (2019). Pengaruh Kompensasi dan Pengalaman Kerja terhadap Kinerja Karyawan pada PT Indo Bali Negara. Bisma: Jurnal Manajemen, Vol. 5 No. 2, Oktober Tahun 2019 P-ISSN: 24768782, 5(2), 112-120.

Hermanto, A. P. (2020). Pengaruh Komunikasi Interpersonal terhadap Tingkat Loyalitas Pelanggan. Intelektiva: Jurnal Ekonomi, Sosial \& Humaniora e-issn 26865661 vol.01 no. 12. Juli 2020, 01(12), 49-59.

kasmir. (2016). Manajemen Sumber Daya Manusia.

Nawa, F., \& Kempa, S. (2017). Pengaruh Kompensasi Dan Disiplin Kerja Terhadap Kinerja Karyawan Pada Pt . Pln ( Persero ) Wilayah Nusa Tenggara Timur. AGORA Vol. 5, No : 3, (2017), 5(3), 1-9.

Nurdin. (2020). Teori Komunikasi Interpersonal.

Pertiwi, Y., Efendi, E., Wijaya, A., \& Simatupang, S. (2019). Pengaruh Komunikasi Interpersonal Dan Kompensasi Terhadap Kepuasan Kerja Pada Pt Perkebunan Nusantara Iii (Persero) Kebun Bangun. SULTANIST: Jurnal Manajemen Dan Keuangan Volume: 7 No: 2 Tahun 2019 Page (11-20) ISSN: 2338-4328 (Print), ISSN: 2686-2646 (Online) Available Online at: Https://Sultanist.Ac.Id/Index.Php/Sultanist PENGARUH, 7(2), 1120. https://doi.org/10.37403/sultanist.v7i2.149

wiryanto. (2020). This study aims at finding out whether Interpersonal Communication between Credit Marketing Officers and Dealers has an effect on the increase in Sales Volume of Two Wheeler Vehicles at PT . Mega Central Finance Medan. The researchers used a quantitative. 9, 72-81. 